\title{
Carcass characteristics of immunocastrated steers finished on diets with different energy patterns
}

\author{
A.F. de Moura ${ }^{1 \#}$, D.C.A. Filho ${ }^{1}$, I.L. Brondani ${ }^{1}$, L.B. Pereira ${ }^{1}$, G. Joner ${ }^{2}$, A.P.M. Martini ${ }^{3}$, R.F. \\ Pacheco $^{4}$, A.R. Mayer ${ }^{5}$, M.B. da Silva ${ }^{1}$ \& D. Borchate ${ }^{1}$ \\ 1Universidade Federal de Santa Maria, Departamento de Zootecnia, Avenida Roraima, № 1000, Camobi, CEP 97105- \\ 900, Santa Maria, RS, Brazil \\ 2Universidade Federal do Pampa, Rua 21 de abril, no 80, São Gregório, CEP 97450-000, Dom Pedrito, RS, Brazil \\ ${ }^{3}$ Universidade Tecnolófica Federal do Paraná, Estrada para Boa Esperança, Km 04, CEP 85660-000, Dois Vizinhos, PR, \\ Brazil \\ ${ }^{4}$ Instituto Federal de Educação, Ciência e Tecnologia Farroupilha, Linha 7 de setembro, s/n, BR 386 - KM 40, \\ CEP:98400-000, Frederico Westphalen, RS, Brazil \\ ${ }^{5}$ Universidade Nilton Lins, Av. Professor Nilton Lins, 3259, Parque das Laranjeiras, CEP: 69058-030, Manaus, AM, Brazil
}

(Submitted 12 December 2018; Accepted; 16 January 2021; Published 22 January 2021)

Copyright resides with the authors in terms of the Creative Commons Attribution 4.0 South African Licence.
See: http://creativecommons.org/licenses/by/4.0/za
Condition of use: The user may copy, distribute, transmit and adapt the work, but must recognise the authors and the South African
Journal of Animal Science.

\begin{abstract}
The aim of this study was to evaluate the effects of various dietary energy levels on the carcass and meat characteristics of feedlot-finished steers. A total of 27 purebred and crossbred Charolais and Nellore steers were used, with a mean initial age of 22 months and weight of $253 \mathrm{~kg}$. The animals were allotted to a completely randomized design with three treatments and nine replicates each. Dietary treatments were arranged so that the average forage to concentrate ratio (FCR) was equivalent to that of a constant FCR treatment. The treatments consisted of CT (constant FCR at 60 to 40), CT5 (starting with 70: 30 FCR and finishing with 50: $50 \mathrm{FCR}$, that is, a mean overall FCR of 60: 40), and CT10 (starting with 80: $20 \mathrm{FCR}$ and finishing with 40: 60, that is, a mean overall FCR of 60: 40). The dietary treatments did not affect slaughter weight, carcass weight, carcass conformation, physiological maturity, subcutaneous fat thickness, ribeye area, marbling score, and carcass measurements or the yield of commercial cuts. Chilling loss was higher in CT10 steers $(2.41 \%)$ than in CT $(2.26 \%)$ and CT5 $(2.15 \%)$.
\end{abstract}

Keywords: beef cattle, Charolais, feedlot, Nellore, forage to concentrate ratio

\# Corresponding author: af.moura@hotmail.com

\section{Introduction}

Adequate feed management is fundamental to successful animal production in which a balance is sought between nutritional intake and the animal's energy requirements (Ribeiro et al., 2011). Current trends towards increasing grain prices and decreasing beef prices motivate a search for alternative feeding programmes for use by farmers that contribute to the economic efficiency of feedlot systems (Peel, 2011).

Cattle feedlot finishing is an essential tool in maximizing animal performance in a short period and in allowing sales at strategic moments (e.g., shortage of animals on the market) to provide a higher remuneration to farmers. However, feedlot economics depends on feeding costs, the purchase price of stocker animals, and the selling price of fattened cattle multiplied by their slaughter weights. In turn, all of these parameters depend on diet quality (Signoretti et al., 2008). But feeding costs are generally high for feedlot-fed animals owing to the prices of grain and by-productS. These high costs affect this technology negatively as about $65 \%$ is usually spent on concentrate feeds (Missio et al., 2009).

Knowledge of the composition of weight gain is as crucial as that associated with the mean daily weight gain. The closer an animal is to the maturity weight, the higher the fat deposition in proportion to protein composition, which will increase demands for weight gain (Marcondes et al., 2016). Thus, an understanding of the requirements and growth curve of cattle allows the diet to be modified and increases the energy supply throughout finishing, since animals demand more energy as they approach adult weight, despite maintaining the same feed input volumes. 
This study aimed to compare a pre-slaughter feeding programme with a FCR of 60: 40 with a preslaughter feeding programme in which the FCR was reduced from 70: 30 to 50: 50 over five 21-day periods, and a pre-slaughter feeding programme in which the FCR was likewise changed from 80: 20 to 40: 60 . Dependent variables of interest were the carcass and meat characteristics of feedlot-finished steers.

\section{Materials and Methods}

The experiment was carried out at the Beef Cattle Laboratory, Animal Science Department of the Federal University of Santa Maria (UFSM), Santa Maria, located in the Central Valley of the State of Rio Grande do Sul, Brazil (95 m above sea level; $29^{\circ} 43^{\prime} \mathrm{S}, 53^{\circ} 42^{\prime} \mathrm{W}$ ). According to Köppen, the climate of the region is classified as 'Cfa' (warm temperate-fully humid-hot summer) (Alvares et al., 2013). All procedures were performed according to the standards and protocols set by the Ethics Committee on Animal Use of UFSM (Protocol No. 5813030715).

A total of 27 purebred and crossbred Charolais and Nellore immunocastrated steers from the experimental herd of the Beef Cattle Laboratory were used in the study. The animals had been immunocastrated with an anti-GnRH vaccine. The animals had a mean initial age of 22 months and a mean bodyweight of $252.8 \mathrm{~kg}$. The steers were distributed so that each treatment contained two purebred Nellore, one purebred Charolais, one 21/32 Nellore, one 21/32 Charolais, one 43/64 Nellore, and three 43/64 Charolais individuals.

The constant FCR diet was formulated to meet NRC requirements (NRC, 1996) of steers and had $13 \%$ crude protein (CP) and an estimated dry matter (DM) intake of $2.5 \mathrm{~kg}$ per $100 \mathrm{~kg}$ of live weight. The two growth rate-related diets were formulated by manipulating the CT diet. Corn silage was used as the sole forage, and the concentrate was composed of ground corn, soybean meal, limestone, and salt (Table 1).

Each animal was considered an experimental unit, and a completely randomized design was used with three treatments and nine replicates. Two treatments were based on the growth rate of the steers (variable forage to concentrate ratio (FCR)), whereas the FCR was kept constant in the third treatment. The growth rate-related treatment diets were arranged so that the average FCR was equivalent to that used in the constant FCR treatment. The CT treatment had a constant FCR (60: 40). The CT5 treatment started with a FCR of 70: 30 with five units of forage removed and five units of concentrate added every 21 days. Thus, at the end of the finishing period the CT5 treatment had a 50: 50 FCR. The CT10 treatment started with an 80:20 FCR with 10 units of forage removed and 10 units of concentrate added every 21 days. Thus, at the end of the finishing period the CT10 treatment had a 40: 60 FCR.

Steers were finished individually in $9.5 \mathrm{~m}^{2}$ covered pens with concrete floors and equipped with feeders and waterers regulated with float valves. Food and water were provided ad libitum. The animals were randomly assigned to treatments and had already been adapted to facilities and diets for 14 days. The control of endoparasites and ectoparasites was performed by subcutaneous application of an ivermectinbased product at $1 \%$, as recommended by the manufacturer. The experiment lasted for 105 days, divided into five periods of 21 days each.

The animals were fed twice a day, at $08 \mathrm{~h} 00$ and $14 \mathrm{~h} 00$. During the experimental period, samples of dietary ingredients and leftovers of each animal were collected, weighed, and pre-dried in a forced-air oven at $55^{\circ} \mathrm{C}$ for 72 hours, then the samples were weighed again to obtain the pre-dry mass. Subsequently, the samples were ground to pass a 1-mm Willey mill sieve and packed into air- and humidity-free plastic bags for further chemical analysis. Samples of leftovers were taken homogeneously three times a week. The DM content was determined by oven drying the samples at $105^{\circ} \mathrm{C}$ until constant weight. The ash content was determined by calcination in a muffle furnace at $550^{\circ} \mathrm{C}$ for 4 hours until constant weight. The organic matter (OM) content was calculated by dividing the DM value by the ash content value. The DM, OM, ash, CP, and EE contents were determined according to the AOAC methodology (1996). The neutral detergent fibre content was determined according to the method described by Van Soest et al. (1991). The total digestible nutrient content was obtained by the in-situ digestibility technique which measured the disappearance of feed from porous bags incubated in the rumen of cannulated cattle for 24 hours and resulted a measure of digestibility of the OM which is equivalent to the TDN (Van Soest, 1994). Digestible energy was calculated according to the NRC method (NRC, 1996) (1 kg TDN = 4.4 Mcal DE).

At the end of the experimental period, the animals were weighed and slaughtered at an average age of 25 months in a commercial slaughterhouse after solid and liquid fasting. After slaughter, the hot carcasses were weighed and then cooled in a cold room, where they were weighed again after 24 hours. The hot and cold carcass yields were obtained as a percentage of the live weight, that is, by dividing the cold or hot carcass weight $(\mathrm{kg})$ by the live slaughter weight and multiplying by 100 . Each cooled carcass was sectioned longitudinally, and the two half-carcasses were evaluated and scored subjectively for conformation and physiological maturity by two trained evaluators (Müller, 1987). The left half carcass was divided into three regions, namely forequarter, hindquarter, and ribs. The individual weights of each region were recorded, and 
the proportion of each region from the left half carcass was calculated in relation to the original carcass weight. The right half carcass was used to determine carcass length, leg length, leg thickness, forearm circumference and length.

Table 1 Forage to concentrate ratio per treatment and period, and nutritional composition of diets fed to feedlot steers with different energy patterns.

\begin{tabular}{|c|c|c|c|c|c|c|c|}
\hline \multirow[b]{2}{*}{ Treatment } & \multirow[b]{2}{*}{ Nutrient } & \multicolumn{5}{|c|}{ 21-day period } & \multirow{2}{*}{ Mean } \\
\hline & & 1 & 2 & 3 & 4 & 5 & \\
\hline \multirow[t]{8}{*}{ CT } & Forage to concentrate & $60: 40$ & $60: 40$ & $60: 40$ & $60: 40$ & $60: 40$ & $60: 40$ \\
\hline & $\mathrm{DM}, \mathrm{g} / \mathrm{kg}$ & 915.71 & 915.78 & 915.81 & 923.3 & 918.6 & 917.83 \\
\hline & $\mathrm{CP}, \mathrm{g} / \mathrm{kg}$ of $\mathrm{DM}$ & 128.93 & 127.53 & 128.02 & 134.1 & 136.2 & 130.95 \\
\hline & $E E, g / k g$ of DM & 25.69 & 25.77 & 25.80 & 26.46 & 27.26 & 26.20 \\
\hline & Ash, $\mathrm{g} / \mathrm{kg}$ of DM & 34.80 & 34.63 & 34.57 & 35.17 & 35.82 & 35.00 \\
\hline & $\mathrm{NDF}, \mathrm{g} / \mathrm{kg}$ of $\mathrm{DM}$ & 368.51 & 368.40 & 368.37 & 364.32 & 368.65 & 367.65 \\
\hline & TDN, $\mathrm{g} / \mathrm{kg}$ of DM & 711.40 & 711.64 & 711.82 & 923.26 & 918.57 & 710.33 \\
\hline & $\mathrm{DE}, \mathrm{Mcal} / \mathrm{kg}$ of DM & 3.13 & 3.13 & 3.13 & 3.12 & 3.11 & 3.13 \\
\hline \multirow[t]{8}{*}{ CT5 } & Forage to concentrate & $70: 30$ & $65: 35$ & $60: 40$ & $55: 45$ & $50: 50$ & $60: 40$ \\
\hline & $\mathrm{DM}, \mathrm{g} / \mathrm{kg}$ & 914.74 & 915.34 & 915.81 & 922.59 & 916.62 & 917.01 \\
\hline & $\mathrm{CP}, \mathrm{g} / \mathrm{kg}$ of $\mathrm{DM}$ & 128.42 & 128.39 & 128.02 & 134.32 & 137.71 & 131.37 \\
\hline & $E E, g / k g$ of $D M$ & 23.16 & 24.44 & 25.80 & 27.72 & 30.13 & 26.25 \\
\hline & Ash, $\mathrm{g} / \mathrm{kg}$ of DM & 37.36 & 36.04 & 34.57 & 33.84 & 33.46 & 35.05 \\
\hline & $\mathrm{NDF}, \mathrm{g} / \mathrm{kg}$ of $\mathrm{DM}$ & 415.34 & 391.89 & 368.37 & 340.99 & 323.93 & 368.10 \\
\hline & TDN, $\mathrm{g} / \mathrm{kg}$ of DM & 682.25 & 696.83 & 711.82 & 723.34 & 735.36 & 709.92 \\
\hline & $\mathrm{DE}, \mathrm{Mcal} / \mathrm{kg}$ of DM & 3.00 & 3.07 & 3.13 & 3.18 & 3.24 & 3.12 \\
\hline \multirow[t]{8}{*}{ CT10 } & Forage to concentrate & $80: 20$ & $70: 30$ & $60: 40$ & $50: 50$ & $40: 60$ & $60: 40$ \\
\hline & $\mathrm{DM}, \mathrm{g} / \mathrm{kg}$ & 912.76 & 914.85 & 915.81 & 922.04 & 915.25 & 916.14 \\
\hline & $\mathrm{CP}, \mathrm{g} / \mathrm{kg}$ of $\mathrm{DM}$ & 127.81 & 127.79 & 128.02 & 134.67 & 139.13 & 131.49 \\
\hline & $E E, g / k g$ of $D M$ & 20.63 & 23.17 & 25.80 & 28.98 & 33.02 & 26.32 \\
\hline & Ash, $\mathrm{g} / \mathrm{kg}$ of DM & 39.92 & 37.31 & 34.57 & 32.51 & 31.09 & 35.08 \\
\hline & $N D F, g / k g$ of $D M$ & 462.18 & 415.29 & 368.37 & 317.66 & 279.26 & 368.55 \\
\hline & TDN, $\mathrm{g} / \mathrm{kg}$ of DM & 652.92 & 682.01 & 711.82 & 738.12 & 764.51 & 709.88 \\
\hline & $\mathrm{DE}, \mathrm{Mcal} / \mathrm{kg}$ of $\mathrm{DM}$ & 2.87 & 3.00 & 3.13 & 3.25 & 3.36 & 3.12 \\
\hline
\end{tabular}

CT: constant 60: 40 FCR, CT5: starting with 70: 30 FCR, and finishing with 50: 50 FCR, CT10: starting with 80: 20 FCR and finishing with 40: 60, DM: dry matter, CP: crude protein, EE: ether extract, NDF: neutral detergent fibre, TDN: total digestible nutrients, DE: digestible energy

The carcass compactness index was calculated from the relationship between the cold carcass weight and length. The HH section at the 10th and 12th rib height was taken (Müller (1987). Then, the Longissimus dorsi area (ribeye area) was outlined on acetate paper $\left(\mathrm{cm}^{2}\right)$, the subcutaneous fat thickness $(\mathrm{mm})$ was measured, and the degree of beef marbling was determined.

Data were tested for normality using the Shapiro-Wilk test. Analysis of variance was done with the GLM procedure of SAS. Significant means were compared with Tukey's test at $5 \%$ significance level. Physiological maturity was analysed using the Kruskal-Wallis test. The analyses were performed with SAS version 3.5 (SAS Institute Inc., Cary, North Carolina, USA). The mathematical model was:

$$
Y_{i j k}=\mu+T_{j}+\varepsilon_{i j k}
$$

where: $Y_{i j k}=$ a dependent variable, $\mu=$ the overall mean, $T_{j}=$ the effect of the jth treatment, and $\varepsilon_{i j k}=$ random error. 


\section{Results and Discussion}

The dietary treatments did not influence the slaughter, hot and cold carcass weights or their yields and commercial cuts (Table 2). The authors had expected animals in the CT5 and CT10 groups to be heavier than those in the CT group because they had been fed diets with higher energy content by the end of the finishing period, which coincided with the phase of higher energy requirement. The hot $(57.82 \%)$ and cold $(56.50 \%)$ carcass yields were both relatively satisfactory, since many slaughterhouses consider that $50 \%$ of the live steer is retained as carcass when buying animals based on live weight (Lopes et al., 2012).

The absolute and relative weights of commercial cuts did not differ between treatments (Table 2), which is explained by the similarity of the slaughter weights of animals. There is a close relationship between the slaughter weight and commercial cuts of steers with different genetic predominance (Silva et al., 2015). The proportion of the hindquarter to the total carcass is essential in beef cattle systems, especially for the slaughterhouses, since the prime cuts, and consequently better-priced cuts, are found in this portion of the carcass (Missio et al., 2010). The average yields of the hindquarter, forequarter, and ribs in this study were $50.91 \%, 38.08 \%$, and $11.74 \%$, respectively. These values were within the desirable range (Luchiari Filho, 2000 ), which stated that the yields of the hindquarter, forequarter, and ribs should be $>48 \%, \leq 39 \%$, and $\leq 13 \%$ in steer carcasses, respectively.

Table 2 Slaughter, hot and cold carcass weights, hot and cold carcass yields, and absolute weights and yields from commercial cuts of carcasses of feedlot-finished steers fed diets with different energy patterns

\begin{tabular}{lrrrrr}
\hline \multirow{2}{*}{ Variable } & \multicolumn{3}{c}{ Treatment } & \multirow{2}{*}{ SE } & P-value \\
\cline { 2 - 4 } & CT & CT5 & CT10 & & \\
\hline Slaughter weight, kg & 415.72 & 416.17 & 402.94 & 12.46 & 0.539 \\
Hot carcass weight, kg & 240.87 & 242.27 & 232.23 & 9.20 & 0.529 \\
Cold carcass weight, kg & 235.43 & 237.08 & 226.63 & 9.02 & 0.497 \\
Hot carcass yield, kg-1 100 kg live weight & 57.90 & 58.01 & 57.54 & 0.69 & 0.882 \\
Cold carcass yield, kg-1 100 kg live weight & 56.60 & 56.76 & 56.15 & 0.68 & 0.807 \\
Forequarter, kg & 90.24 & 89.82 & 86.40 & 3.83 & 0.711 \\
Forequarter, kg 100 kg-1 of cold carcass & 38.27 & 37.90 & 38.07 & 0.44 & 0.835 \\
Rib, kg & 27.80 & 28.44 & 25.73 & 1.16 & 0.246 \\
Rib, kg 100 kg-1 of cold carcass & 11.83 & 11.97 & 11.41 & 0.28 & 0.337 \\
Hindquarter, kg & 118.84 & 121.13 & 116.22 & 4.68 & 0.526 \\
Hindquarter, kg 100 kg-1 of cold carcass & 50.47 & 51.10 & 51.27 & 0.46 & 0.451 \\
\hline
\end{tabular}

CT: constant 60: 40 FCR, CT5: starting with 70: 30 FCR, and finishing with 50: 50 FCR, CT10: starting with 80: 20 FCR and finishing with 40:60

No differences were observed between treatments for subcutaneous fat thickness, and the conformation values were similar (Table 3 ). This may have been caused by the similarity in hot carcass weight, which also reflects carcass muscularity (Rodrigues et al., 2015).

Chilling loss, which corresponds to the loss in carcass weight during the first 24 hours of chilling after slaughter (Menezes et al., 2010), was higher in CT10 steers than in the CT and CT5 groups. Chilling is critical to meat hygiene, safety, shelf life, appearance, and eating quality (Ockerman \& Basu, 2014). Chilling loss is influenced primarily by carcass fat thickness, which is also considered an important parameter when evaluating the final product (Lage et al., 2012). Carcass shrinks of $2.41 \%$ are considered high (Vaz et al., 2013). However, studies that evaluated various animal categories and diets reported similar means of $2.36 \%$ (Silva et al., 2015), 2.70\% (Olmedo et al., 2011), 2.46\% (Menezes et al., 2010), and 2.19\% (Missio et al., 2010). Based on these values in the literature, the higher carcass shrink did not compromise the cold carcass weight and yield in CT10 steers. 
Table 3 Conformation, physiological maturity, chilling loss, subcutaneous fat thickness, ribeye area, marbling, and carcass traits of feedlot-finished steers fed diets with various energy patterns

\begin{tabular}{|c|c|c|c|c|c|}
\hline \multirow{2}{*}{ Variable } & \multicolumn{3}{|c|}{ Treatment } & \multirow{2}{*}{ SE } & \multirow{2}{*}{ P-value } \\
\hline & CT & CT5 & CT10 & & \\
\hline Conformation, points ${ }^{1}$ & 9.67 & 9.89 & 8.67 & 0.59 & 0.312 \\
\hline Physiological maturity, points ${ }^{2}$ & 13.56 & 13.67 & 13.44 & 0.17 & 0.648 \\
\hline Chilling loss, $\mathrm{kg} 100-1 \mathrm{~kg}$ of cold carcass & $2.26^{\mathrm{b}}$ & $2.15^{\mathrm{b}}$ & $2.41^{\mathrm{a}}$ & 0.04 & $<0.01$ \\
\hline Subcutaneous fat thickness, $\mathrm{mm}$ & 3.86 & 4.78 & 3.40 & 0.53 & 0.168 \\
\hline Longissimus dorsi area, $\mathrm{cm}^{2}$ & 71.59 & 71.28 & 62.97 & 3.39 & 0.146 \\
\hline Marbling, points ${ }^{3}$ & 6.44 & 6.11 & 6.33 & 0.94 & 0.968 \\
\hline Carcass length, $\mathrm{cm}$ & 122.44 & 121.50 & 122.28 & 1.40 & 0.921 \\
\hline Leg length, cm & 70.67 & 71.16 & 71.56 & 0.99 & 0.819 \\
\hline Forearm length, $\mathrm{cm}$ & 36.39 & 37.00 & 36.56 & 0.84 & 0.867 \\
\hline Forearm circumference, $\mathrm{cm}$ & 37.50 & 36.63 & 36.50 & 0.88 & 0.689 \\
\hline Leg thickness, $\mathrm{cm}$ & 26.69 & 26.13 & 26.13 & 0.59 & 0.711 \\
\hline Compactness, $\mathrm{kg} \mathrm{cm}^{-1}$ & 1.92 & 1.94 & 1.85 & 0.06 & 0.537 \\
\hline
\end{tabular}

${ }^{a, b}$ Within a row, values with a common superscript were not different at probability $P=0.05$

CT: constant 60: 40 FCR, CT5: starting with 70: 30 FCR, and finishing with 50: 50 FCR, CT10: starting with 80: 20 FCR and finishing with 40: 60

${ }_{1} 1$ - 3: poor; 4 - 6: inferior; 7 - 9: regular; 10 - 12: good; 13 - 15: very good; 16 - 18: superior

${ }_{1} 1-3$ : >8 years old; 4 - 6: 5.5-8 years old; 7 - 9: 4-5.5 years old; $10-12: 2.5-4$ years old; $12-15:<2.5$ years old

31 - 3: traces; 4 - 6: slight; 7 - 9: small; 10 - 12: modest; 13 - 15: moderate; 16 - 18: abundant

Fat deposition follows the order in which internal fat is deposited first, followed by intermuscular, subcutaneous, and finally by intramuscular or marbling fat (Paulino et al., 2009). Therefore, higher levels of fat, primarily subcutaneous and intramuscular, were expected in CT10 steers. These animals had higher energy intake during the phase in which fat was deposited in greater amounts as they approached slaughter weight. Thus, more time would be needed to ensure higher energy input and late fat deposition.

The subcutaneous fat thickness did not differ between treatments and was higher than $3 \mathrm{~mm}$, which is the minimum recommended by Brazilian slaughterhouses (Freitas et al., 2008). Differences were expected in CT5 and CT10 animals because of the higher energy intake in the late finishing period. The current results corroborate those of Missio et al. (2010), who did not find differences in subcutaneous fat thickness in feedlot steers with the same slaughter weight and fed diets containing $22 \%, 40 \%, 59 \%$, and $79 \%$ concentrate. On the other hand, Diniz et al. (2016) observed a mean chilling loss of $3.13 \%$ in a study that evaluated the carcass and meat characteristics of crossbred Guzerá steers, which was associated with the low subcutaneous fat thickness (mean $2.13 \mathrm{~mm}$ ).

There was no difference between treatments for the ribeye area owing to its high correlation with slaughter and hot and cold carcass weights (Table 2). The ribeye area is an indicator of carcass composition as it reflects carcass muscularity (Freitas et al., 2008). In a study with steers with ages and genetic compositions that were similar to those in the current study, but with a lower slaughter weight, Cattelam et al. (2013) reported a mean Longissimus dorsi area of $58.27 \mathrm{~cm}^{2}$. On the other hand, Signoretti et al. (2008) reported a mean ribeye area of $66.59 \mathrm{~cm}^{2}$ for Nellore steers fed corn silage-based diets, which is similar to the value reported in the present study $\left(68.61 \mathrm{~cm}^{2}\right)$.

A small degree of marbling or intramuscular fat was found in all treatment groups (Table 3). Marbling is one of the most critical factors that determine meat quality (Peña et al., 2013). Both the Charolais and Nellore cattle have a small degree of marbling in the meat (Mayer, 2017), with reduced marbling until 24 months old (Chambaz et al., 2002; Chardulo et al., 2013).

Significant differences were not found for carcass measurement traits. This corroborates a previous study (Hirai et al., 2014), which found no differences in carcass measurement traits between animals with the same genetic patterns and similar ages at slaughtering. When standardized for weight, carcass measurements are a straightforward indicator of carcass conformation (Campion et al., 2009), which may 
explain the similarity in carcass conformation characteristics between treatments. Moreover, Olmedo et al. (2011) stated that these characteristics are related mainly to breed and age.

The carcass compactness index averaged $1.90 \mathrm{~kg} \mathrm{~cm}^{-1}$ and did not differ between treatments. These results are similar to those obtained by Cattelam et al. (2013), who evaluated animals of similar age, breed, and weight. Overall, the current results are in line with the pattern of the animals since the carcass compactness index and measurement traits are associated mainly with the animal's weight and age (Olmedo et al., 2011).

\section{Conclusions}

Feeding various energy levels during the finishing phase resulted in higher carcass shrink, but did not compromise the weights, yields, and commercial cuts of carcasses. These dietary energy levels did not influence the qualitative characteristics of the carcasses and meat from feedlot-finished steers.

\section{Acknowledgements}

This study was financed in part by the Coordenação de Aperfeiçoamento de Pessoal de Nível Superior - Brasil (CAPES) - Finance Code 001".

\section{Authors' Contributions}

AFM, DCAF, RFP and ARM contributed to the project idea, design and execution of the study. LBP, GJ, APMM, MBS and DB participated in the acquisition of data. MBS and DB contributed to laboratory analyses. AFM and RFP analysed the data. AFM drafted and wrote the manuscript. Critical reviews were made by DCAF and ILB. All authors have read and approved the finalized manuscript.

\section{Conflict of Interest Declaration}

The authors declare that there was no conflict of interest regarding the material in this manuscript.

\section{References}

Alvares, C.A., Stape, J.L., Sentelhas, P.C., Moraes, G., Leonardo, J. \& Sparovek, G., 2013. Köppen's climate classification map for Brazil. Meteorol. Z. 22, 711-728. DOI: 10.1127/0941-2948/2013/0507

AOAC, 1996. Official methods of analysis of AOAC International. 16th ed. Association of Official Analytical Chemists, Gaithersburg, MD.

Campion, B., Keane, M.G., Kenny, D.A. \& Berry, D.P., 2009. Evaluation of estimated genetic merit for carcass weight in beef cattle: Blood metabolites, carcass measurements, carcass composition and selected non-carcass components. Livest. Sci. 126, 100-111. DOI: 10.1016/j.livsci.2009.06.003

Cattelam, J., Brondani, I.L., Alves Filho, D.C., Segabinazzi, L.R., Callegaro, A.M. \& Cocco, J.M., 2013. Características de carcaça e qualidade da carne de novilhos confinados em diferentes espaços individuais. Cienc. Anim. Bras. 14, 185-198. DOI: 10.5216/cab.v14i2.22703 (in Portuguese, English abstract).

Chambaz, A., Scheeder, M.R.L., Kreuzer, M. \& Dufey, P.A., 2003. Meat quality of Angus, Simmental, Charolais and Limousin steers compared at the same intramuscular fat content. Meat Sci. 63, 491-500. DOI: 10.1016/s03091740(02)00109-2

Chardulo, L.A.L., Silveira, A.C. \& Vianello F., 2013. Analytical aspects for tropical meat quality assessment. In: G.P.P. Lima, \& F. Vianello (eds). Food quality, safety and technology. Springer, Vienna. DOI: 10.1007/978-3-7091-164014

Diniz, F.B., Villela, S.D.J., Mourthé, M.H.F., Paulino, P.V.R., Boari, C.A., Ribeiro, J.S., Barroso, J.A., Pires, A.V. \& Martins, P.G.M.A., 2016. Evaluation of carcass traits and meat characteristics of Guzerat-crossbred bulls. Meat Sci. 112, 58-62. DOI: 10.1016/j.meatsci.2015.10.014

Freitas, A.K., Restle, J., Pacheco, P.S., Padua, J.T., Lage, M.E., Miyagi, E.S. \& Silva, G.F.R., 2008. Características de carcaças de bovinos Nelore inteiros vs castrados em duas idades, terminados em confinamento. R. Bras. Zootec., 37, 1055-1062. DOI: 10.1590/S1516-35982008000600016 (in Portuguese, English abstract).

Hirai, M.M.G, Menezes, L.F.G., Kuss, F., Vonz, D., Ronsani, R., Martinello, C., Nazário, D. \& Segabinazzi, L.R., 2014. Características de carcaça e qualidade da carne de novilhos terminados em pastagem de aveia branca. Semina: Ciênc. Agrár. 35, 2617-2628. DOI: 10.5433/1679-0359.2014v35n4Suplp2617 (in Portuguese, English abstract).

Lage, J.F., Paulino, P.V., Filho, S.C., Souza, E.J., Duarte, M.S., Benedeti, P.D., Souza, N.K. \& Cox, R.B., 2012. Influence of genetic type and level of concentrate in the finishing diet on carcass and meat quality traits in beef heifers. Meat Sci. 90, 770-774. DOI: 10.1016/j.meatsci.2011.11.012

Lopes, L.S., Ladeira, M.M., Machado Neto, O.R., Paulino, P.V.R., Chizzotti, M.L., Ramos, E.M. \& Oliveira, D.M., 2012. Características de carcaça e cortes comerciais de tourinhos Red Norte e Nelore terminados em confinamento. R. Bras. Zootec. 41, 970-977. DOI:. 101590/S1516-35982012000400020 (in Portuguese, English abstract).

Luchiari Filho, A., 2000. Pecuária da carne bovina. R Vieira Gráfica e Editora, São Paulo, Brazil.

Marcondes, M.I., Tedeschi, L.O., Valadares Filho, S.C., Costa e Silva, L.F. \& Silva, A.L., 2016. Using growth and body composition to determine weight at maturity in Nellore cattle. Animal Prod. Sci. 56, 1121-1129. DOI: 10.1071/AN14750 
Mayer, A.M., 2017. Análise multivariada para características de desempenho, carne e carcaça de uma população multirracial Charolês-Nelore. PhD (Anim Sci) thesis, Universidade Federal de Santa Maria, Brasil. (in Portugese, English abstract).

Menezes, L.F.G., Restle, J., Brondani, I.L., Silveira, M.F., Freitas, L.S. \& Pizzuti, L.A.D., 2010. Características da carcaça e da carne de novilhos superjovens da raça Devon terminados em diferentes sistemas de alimentação. R. Bras. Zootec. 39, 667-676. DOI: 10.1590/S1516-35982010000300028 (in Portuguese, English abstract).

Missio, R.L., Brondani, I.L., Freitas, L.S., Sachet, R.H., Silva, J.H.S. \& Restle, J., 2009. Desempenho e avaliação econômica da terminação de tourinhos em confinamento alimentados com diferentes níveis de concentrado na dieta. R. Bras. Zootec. 38, 1309-1316. DOI: 10.1590/S1516-35982009000700021 (in Portuguese, English abstract).

Missio R.L., Brondani, I.L., Alves Filho, D.C., Restle, J., Arboitte, M.Z. \& Segabinazzi, L.R., 2010. Características da carcaça e da carne de tourinhos terminados em confinamento, recebendo diferentes níveis de concentrado na dieta. R. Bras. Zootec. 39, 1610-1617. DOI: 10.1590/S1516-35982010000700030 (in Portuguese, English abstract).

Müller, L., 1987. Normas para avaliação de carcaças e concurso de novilhos. 2nd ed. Universidade Federal de Santa Maria, Santa Maria

NRC, 1996. Nutrient requirements of beef cattle. 7th ed. National Academy Press, Washington, DC, USA.

Ockerman, W. \& Basu, L., 2014. Carcass chilling and boning. In: M. Dikeman \& C. Devine (eds). Encyclopedia of meat sciences. 2nd edition. Academic Press, Cambridge, Massachusetts.

Olmedo, D.O., Barcellos, J.O.J, Canellas, L.C., Velho, M.M.S., Paniagua, P., Horitá, I. \& Tarouco, J.U., 2011. Desempenho e características da carcaça de novilhos terminados em pastejo rotacionado ou confinamento. Arq. Bras. Med. Vet. Zootec. 63, 348-355. DOI: 10.1590/S0102-09352011000200012 (in Portuguese, English abstract).

Paulino, P.V.R., Valadares Filho, S.C., Detmann, E., Valadares, R.F.D., Fonseca, M.A. \& Marcondes, M.I., 2009. Deposição de tecidos e componentes químicos corporais em bovinos Nelore de diferentes classes sexuais. R. Bras. Zootec. 38, 2516-2524. DOI: 10.1590/S1516-35982009001200030 (in Portuguese, English abstract).

Peel, D.S., 2011. Market coordination in the beef stocker sector: Short and long run implications of higher corn prices. Southern Agricultural Economics Association Annual Meeting, Texas. https://ageconsearch.umn.edu/record/98826/files/Market\%20Coordination\%20in\%20the\%20Beef\%20Stocker\%20 Sectorx.pdf

Peña, F., Molina, A., Avilés, C., Juárez, M. \& Horcada, A., 2013. Marbling in the longissimus thoracis muscle from lean cattle breeds. Computer image analysis of fresh versus stained meat samples. Meat Sci. 95, 512-519. DOI: 10.1016/j.meatsci.2013.05.036

Rlbeiro, E.L.A., Mizubuti, I.Y., Silva, L.D.F., Paiva, F.H.P., Sousa, C.L. \& Castro, F.A.B., 2011. Desempenho, comportamento ingestivo e características de carcaça de cordeiros confinados submetidos a diferentes frequências de alimentação. R. Bras. Zootec. 40, 892-898. DOI: 10.1590/S1516-35982011000400025 (in Portuguese, English abstract).

Rodrigues, L.S., Moura, A.F., Pacheco, R.F., Paula, P.C., Brondani, I.L. \& Alves Filho, D.C., 2015. Características da carcaça e da carne de vacas de descarte abatidas com distintos pesos e grau de acabamento - abordagem meta-analítica. Cienc. Anim. Bras. 16, 508-516. DOI: 10.1590/1089-6891v16i434519 (in Portuguese, English abstract).

Signoretti, R.D., Sampaio, R.L., Resende, F.D., Coan, R.M., Reis, R.A., Alleoni, G.F., Faria, M.H., Siqueira, G.R. \& Miguel, F.B., 2008. Ganho de peso vivo diário, conversão alimentar e características de carcaça de novilhos da raça nelore, confinados e alimentados com dietas baseadas em silagens de capim marandu ou de milho. Bol. Ind. Anim. 65, 71-82. http://www.iz.sp.gov.br/bia/index.php/bia/article/view/1148 (in Portuguese, English abstract).

Silva, R.M., Restle, J., Missio, R.L., Bilego, U.O., Pacheco, P.S., Rezende, P.L.P., Fernandes, J.J.R., Silva, A.H.G. \& Pádua, J.T., 2015. Características de carcaça e carne de novilhos de diferentes predominâncias genéticas alimentados com dietas contendo níveis de substituição do grão de milho pelo grão de milheto. Semina: Ciênc. Agrár. 36, 943-960. DOI: 10.5433/1679-0359.2015v36n2p943 (in Portuguese, English abstract).

Van Soest, P.J., Robertson, J.B. \& Lewis, B.A., 1991. Symposium: Carbohydrate methodology, metabolism, and nutritional implications in dairy cattle. J. Dairy Sci. 74, 3583-3597.

Van Soest, P.J., 1994. Nutritional ecology of the ruminant. 2nd ed. Cornell University Press, Ithaca, NY, USA.

Vaz, F.N., Restle, J., Pádua, J.T., Fonseca, C.A. \& Pacheco, P.S., 2013. Características de carcaça e receita industrial com cortes primários da carcaça de machos nelore abatidos com diferentes pesos. Cienc. Anim. Bras. 14, 199207. DOI: 10.5216/cab.v14i2.21123 (in Portuguese, English abstract). 